\title{
PENGARUH PENERAPAN MODEL PEMBELAJARAN BERBASIS MASALAH BERBANTUAN SIMULASI INTERAKTIF TERHADAP HASIL BELAJAR FISIKA SISWA KELAS VIII SMPN 1 PUJUT TAHUN PELAJARAN $2013 / 2014$
}

\author{
Winarni Listiawati' ${ }^{1}$, Gunawan' ${ }^{2}$, Sutrio $^{2}$ \\ 1) Alumni Program Studi Pendidikan Fisika \\ 2) Program Studi Pendidikan Fisika \\ Universitas Mataram \\ Mataram, Indonesia \\ Email: winarni.listiawati@yahoo.com
}

\begin{abstract}
This research is a quasi-experimental aims to finding out the impact of problem-based learning model assist with interactive simulation of the results of learning physics of grade VIII SMPN 1 Pujut in academic year 2013/2014. The design of this research used of non-equivalent control group design, while the sampling technique used purposive sampling. The population of this research is students of grade VIII SMPN 1 Pujut with 227 students, while the sampling are the students of grade VIII 1 as the experimental group and the students of grade VIII 6 as control group. The data result studying analyzed by t-test two tail using formulas polled variance. Obtain values $t_{\text {hint }}=2,519$ and $t_{\text {table }}=2,013$ on degree of free is 47 with $5 \%$ significant degree. Because $t_{\text {hint }}>t_{\text {table }}$, then $H_{0}$ will be rejected and $H_{a}$ will be accepted which indicates that there is significant the impact of problem-based learning model assist with interactive simulation of the results of learning physics grade VIII SMPN 1 Pujut in academic year 2013/2014.
\end{abstract}

Keywords : problem-based learning, interactive simulation, and the results of learning physic.

\section{Pendahuluan}

Ilmu Pengetahuan Alam (IPA) pada hakikatnya merupakan suatu produk, proses, dan sikap. Sebagai produk, IPA merupakan hasil penemuan dari berbagai kegiatan penyelidikan atau penelitian yang berupa fakta, konsep, prinsip, hukum-hukum, dan teori atau pun model. Sebagai suatu proses, IPA merupakan proses untuk menemukan, mengembangkan dan menguji informasi ilmiah yang telah diperoleh. IPA sebagai sikap diartikan sebagai proses penemuan, pengamatan, pengukuran, dan penyelidikan ilmiah yang dilakukan memerlukan proses mental dan sikap yang berasal dari suatu pemikiran yang ilmiah [1].

Salah satu cabang dari IPA yang lahir dan berkembang melalui langkah-langkah observasi, perumusan masalah, penyusunan hipotesis, pengujian hipotesis melalui eksperimen, penarikan kesimpulan serta penemuan fakta, teori dan konsep adalah Fisika [2]. Salah satu tujuan dari pembelajaran fisika yang tertuang dalam kurikulum 2013 adalah mendorong siswa untuk menemukan dan mentransformasikan informasi kompleks, mengecek informasi baru dengan aturan-aturan lama di dalam pikirannya, dan merevisinya apabila aturan-aturan itu tidak lagi sesuai. Selain itu siswa juga didorong untuk mengonstruksi pengetahuannya di dalam pikirannya dan bekerja memecahkan masalah agar siswa benarbenar memahami dan dapat menerapkan pengetahuannya. Sehingga hal ini menuntut keaktifan siswa yang lebih selama proses pembelajaran berlangsung. Keaktifan siswa yang dimaksud adalah upaya siswa untuk menemukan sendiri pemecahan masalah yang mereka hadapi terkait dengan pembelajaran fisika.

Berkaitan dengan pembelajaran fisika di sekolah belum sesuai dengan tujuan yang diharapkan. Pembelajaran fisika yang diterapkan masih berlangsung klasikal dan hanya bergantung pada buku teks dengan metode menghafal daripada memahami konsep. Metode mengajar yang dikembangkan dominan ceramah sehingga pembelajaran berpusat pada guru (teacher center). Aktivitas ini dinilai kurang optimal karena hanya membentuk interaksi searah saja, yaitu interaksi guru terhadap siswa.

Kondisi proses pembelajaran fisika pada siswa kelas VIII SMPN 1 Pujut berdasarkan hasil observasi dan wawancara dengan salah satu guru, didapatkan bahwa siswa kurang termotivasi belajar fisika. Siswa cenderung hanya mendengarkan dan mencatat informasi-informasi yang diberikan. Selain itu, kegiatan praktikum fisika jarang dilakukan. Hal ini disebabkan karena laboratorium yang seharusnya dijadikan tempat bereksperimen dijadikan ruangan kelas. Sedangkan menurut keterangan beberapa siswa, pelajaran fisika itu sulit karena begitu banyak 
rumus yang harus mereka hafalkan. Selain itu fisika juga dianggap tidak menarik serta membosankan. Hal ini berdampak pada hasil belajar siswa rendah yang masih berada di bawah KKM, yakni 65 .

Berdasar pada uraian tersebut, diberikan suatu alternatif solusi pembelajaran yakni dengan menerapkan suatu model pembelajaran yang dapat memberikan keleluasaan pada siswa untuk membangun pengetahuannnya dan menemukan atau menerapkan sendiri ide-ide mereka sehingga terlibat secara aktif dalam proses pembelajaran yakni dengan menerapkan model pembelajaran berbasis masalah. Model pembelajaran ini berlandaskan perspektif kognitif konstruktivis yaitu siswa terlibat secara aktif dalam proses mendapatkan informasi dan mengonstruksikan pengetahuannya sendiri [3]. Kelebihan model pembelajaran berbasis masalah yakni merupakan suatu pembelajaran yang berpusat pada siswa (student-centered) sehingga proses pembelajaran menjadi bermakna karena adanya pengalaman nyata dari siswa. Pengalaman nyata inilah yang menyebabkan siswa dapat membentuk keaktifannya dalam belajar, sehingga dapat meningkatkan motivasi dan hasil belajar siswa.

Untuk lebih mengoptimalkan keaktifan belajar siswa, peneliti menggunakan bantuan media pembelajaran simulasi interaktif. Simulasi interaktif memberikan kesempatan untuk belajar secara dinamis, interaktif dan perorangan. Dengan simulasi interaktif, lingkungan pekerjaan yang kompleks dapat ditata hingga menyerupai dunia nyata [4]. Tujuan dari penggunaan simulasi interaktif adalah untuk memberikan kondisi yang menyerupai keadaan sebenarnya sehingga mengurangi pengambilan persepsi yang ambigu dan abstrak serta menarik minat belajar siswa dengan menampilkan simulasisimulasi yang menarik sehingga penyampaian materi tidak monoton.

Pada akhirnya dengan diterapkannya model pembelajaran ini siswa tidak hanya sekedar mendengarkan, mencatat, kemudian menghafal materi pelajaran. Akan tetapi, siswa aktif berfikir, berkomunikasi, mencari dan mengolah data, dan akhirnya menyimpulkan. Dengan demikian dapat meningkatkan hasil belajar fisika siswa.

\section{METODE PENELITIAN}

Jenis penelitian ini adalah penelitian eksperimen yaitu metode penelitian yang digunakan untuk mencari pengaruh perlakuan tertentu terhadap yang lain dalam kondisi yang terkendalikan. Penelitian eksperimen meneliti ada tidaknya hubungan sebab akibat dan berapa besar hubungan sebab akibat tersebut dengan cara memberi perlakuan tertentu pada beberapa kelompok eksperimen dan menyediakan kontrol sebagai perbandingan [5].
Penelitian ini dilaksanakan dari tanggal 12 Oktober 2013 sampai dengan 26 Juli 2014 di kelas VIII SMPN 1 Pujut Tahun Pelajaran 2013/2014. Desain penelitian menggunakan Nonequivalent Control Group Design. Adapun teknik pengambilan sampel yang digunakan adalah purposive sampling, yaitu teknik pengambilan sampel dengan alasanalasan tertentu. Dalam penelitian ini yang dijadikan sampel yaitu kelas VIII 1 sebagai kelas eksperimen dan VIII 6 sebagai kelas kontrol.

Prosedur kegiatan penelitian ini dilakukan dalam tiga tahap yaitu :

\section{Tahap Persiapan}

Pada tahap persiapan, peneliti mempersiapkan segala sesuatu yang dibutuhkan pada saat penelitian yang meliputi: (1) Melakukan observasi di sekolah terkait kegiatan belajar-mengajar dan fasilitas di SMPN 1 Pujut. (2) Menentukan materi pokok yang akan diajarkan dengan model pembelajaran berbasis masalah berbantuan simulasi interaktif. (3) Membuat instrumen penelitian yang mencakup silabus, RPP, dan LKS. (4) Membuat instrumen penilaian tes hasil belajar berupa tes obyektif berbentuk pilihan ganda sebanyak 40 soal. (5)Menentukan dan menyiapkan simulasi interaktif yang digunakan di dalam pembelajaran. (6) Mengelompokkan sampel menjadi kelas kontrol dan kelas eksperimen. (7) Melakukan uji coba instrumen tes hasil belajar. (8) Menganalisis hasil uji instrumen yakni dengan menghitung validitas, reliabilitas, taraf kesukaran dan daya beda soal untuk instrumen hasil belajar. (9) Melakukan tes awal kepada kedua kelas sampel dengan menggunakan tes yang telah diuji sebelumnya.

\section{Tahap Pelaksanaan}

Kegiatan yang dilaksanakan pada tahap ini adalah memberikan perlakuan kepada kelas eksperimen berupa model pembelajaran berbasis masalah berbantuan simulasi interaktif. Dan memberikan perlakuan kepada kelas kontrol berupa model pembelajaran berbasis masalah tanpa bantuan simulasi interaktif. Kemudian pada kedua kelas sampel diberikan tes akhir.

\section{Tahap Akhir}

Pada tahap akhir ini dilakukan analisis data penelitian, menyimpulkan data penelitian, dan membuat laporan hasil penelitian.

Pada penelitian ini ada tiga variabel yang menjadi fokus penelitian yaitu variabel bebas, variabel kontrol, dan variabel terikat. Variabel bebas pada penelitian ini adalah model pembelajaran, variabel terikat adalah hasil belajar fisika siswa, dan variabel kontrolnya adalah materi, tujuan pembelajaran, instrumen yang digunakan, dan cara penilaiannya sama. Teknik pengumpulan data pada penelitian ini adalah tes hasil belajar. Data hasil belajar merupakan 
data tes awal sebelum diberikan perlakuan dan tes akhir yang dilakukan setelah perlakuan. Data tes awal dan tes akhir diperoleh dengan menggunakan instrumen yang telah diujicobakan kepada 28 orang siswa kelas VIII yang sudah menerima materi cahaya sebelumnya, kemudian hasil tes tersebut diukur dengan uji validitas, reliabilitas, tingkat kesukaran, dan daya beda soal. Berdasarkan hasil uji coba 40 butir soal diperoleh 30 butir soal yang baik digunakan untuk tes awal dan tes akhir. Analisis validitas instrumen menggunakan rumus product moment untuk menguji validitas soal dan untuk uji reliabilitas soal menggunakan rumus Spearman-Brown, indeks kesukaran soal untuk tingkat kesukaran, dan indeks diskriminasi untuk daya beda soal. Analisis data tes akhir menggunakan uji-t dua pihak, yang sebelumnya telah diuji homogenitas sampel menggunakan uji-F dan normalitas data menggunakan uji Chi Kuadrat. Sedangkan untuk mengetahui peningkatan hasil belajar siswa per sub materi digunakan uji N-Gain.

\section{Hasil dan Pembahasan}

Hasil penelitian berupa deskripsi hasil tes awal dan tes akhir dengan menggunakan uji homogenitas, uji normalitas dan uji hipotesis (uji-t dua pihak). Adapun hasil rekapitulasi nilai tes awal pada kelas kontrol dan kelas eksperimen materi cahaya dapat dilihat pada tabel berikut.

Tabel 1 Rekapitulasi Nilai Tes Awal pada Kedua Kelas Sampel

\begin{tabular}{lcc}
\hline Komponen & $\begin{array}{c}\text { Kemampuan Awal } \\
\text { Kelas } \\
\text { Kontrol }\end{array}$ & $\begin{array}{c}\text { Kelas } \\
\text { Eksperimen }\end{array}$ \\
\hline Jumlah siswa & 24 & 25 \\
Nilai tertinggi & 53 & 47 \\
Nilai terendah & 17 & 13 \\
Rata-rata & 33.33 & 26.96 \\
Standar & 8.26 & 9.25 \\
Deviasi (SD) & \multicolumn{2}{c}{ Homogen } \\
\hline Uji & \multicolumn{2}{c}{ Normal } \\
Homogenitas & Normal \\
Uji Normalitas & \multicolumn{2}{c}{} \\
\hline
\end{tabular}

Data hasil penelitian menunjukkan bahwa nilai rata-rata tes awal siswa pada kedua sampel sebesar 33.33 untuk kelas kontrol dan 26.96 untuk kelas eksperimen. Pada tabel 1, menunjukkan bahwa kelas kontrol dan kelas eksperimen homogen yang berarti kedua kelas dampel memiliki kemampuan awal yang sama. Selain itu, hasil rata-rata tes awal yang rendah disebabkan karena kedua kelas belum memperoleh materi cahaya yang sesuai dengan jenjang pendidikannya. Pengetahuan yang mereka miliki hanya berupa pengetahuan dasar tentang cahaya yang dulunya pernah mereka peroleh di sekolah dasar.
Tabel 2 Rekapitulasi Nilai Tes Akhir pada Kedua Kelas Sampel

\begin{tabular}{|c|c|c|}
\hline \multirow[b]{2}{*}{ Komponen } & \multicolumn{2}{|c|}{ Kemampuan Akhir } \\
\hline & $\begin{array}{c}\text { Kelas } \\
\text { Kontrol }\end{array}$ & $\begin{array}{c}\text { Kelas } \\
\text { Eksperimen }\end{array}$ \\
\hline Jumlah siswa & 24 & 25 \\
\hline Nilai tertinggi & 80 & 93 \\
\hline Nilai terendah & 50 & 60 \\
\hline Rata-rata & 69.71 & 76.00 \\
\hline $\begin{array}{l}\text { Standar } \\
\text { Deviasi (SD) }\end{array}$ & 9.13 & 83.35 \\
\hline $\begin{array}{l}\text { Uji } \\
\text { Homogenitas }\end{array}$ & Homogen & \\
\hline Uji Normalitas & Normal & Normal \\
\hline Uji Hipotesis & $\begin{array}{l}t_{\text {hitung }}>t_{\text {tabe }} \\
\mathrm{H}_{\mathrm{a}} \text { diterima }\end{array}$ & $H_{\mathrm{o}}$ ditolak dan \\
\hline
\end{tabular}

Setelah dilakukan tes awal selanjutnya kedua kelas sampel diberi perlakuan yang berbeda dan terakhir dilakukan tes akhir. Berdasarkan hasil tes akhir siswa terjadi peningkatan nilai rata-rata tes akhir dari nilai rata-rata tes awal. Jika dibandingkan peningkatan nilai rata-rata tes akhir kedua kelompok sampel, terlihat bahwa siswa kelas eksperimen dengan model pembelajaran berbasis masalah berbantuan animasi menujukkan peningkatan yang lebih tinggi daripada siswa kelas kontrol dengan pembelajaran berbasis maslah tanpa berbantuan simulasi interaktif seperti yang terlihat pada tabel 2 . Selanjutnya hasil tes akhir ini juga digunakan untuk perhitungan uji homogenitas dan normalitas sehingga diperoleh bahwa kedua kelas setelah diberi perlakuan memiliki varians yang homogen dan terdistribusi normal. Setelah mengetahui homogenitas dan normalitas kedua kelas kemudian dilakukan uji hipotesis dengan taraf signifikan $5 \%$ dimana diperoleh $t_{\text {hitung }}=2.519$ lebih besar dari $t_{\text {tabel }}=2.013$. Hal ini berarti terdapat perbedaan hasil belajar fisika menggunakan model pembelajaran berbasis masalah berbantuan simulasi interaktif dengan pembelajaran berbasis masalah tanpa berbantuan simulasi interaktif pada siswa SMPN 1 Pujut tahun pelajaran 2013/2014. Sehingga dapat disimpulkan bahwa model pembelajaran berbasis masalah berbantuan simulasi interaktif berpengaruh terhadap hasil belajar fisika siswa kelas VIII SMPN 1 Pujut tahun pelajaran 2013/2014.

Adapun penelitian sebelumnya yang mendukung penelitian ini menunjukkan bahwa penerapan Problem-Based Instruction dapat meningkatkan hasil belajar fisika siswa [6]. Selanjutnya dalam penelitian yang berkaitan dengan penggunaan simulasi interaktif menunjukkan bahwa model pembelajaran berbasis masalah berbantuan simulasi interaktif berpengaruh positif terhadap penguasaan konsep dan keterampilan generik sains siswa [7]. 
Selain melakukan analisis pengujian hipotesis, peneliti juga ingin mengetahui sejauh mana peningkatan yang dialami kedua kelas secara lebih terperinci terkait hubungan nilai antara kelas kontrol dan kelas eksperimen untuk presentase kenaikan hasil belajar tiap sub materi. Perbandingan peningkatan hasil hasi belajar siswa per sub materi cahaya tersaji dalam Diagram 1.

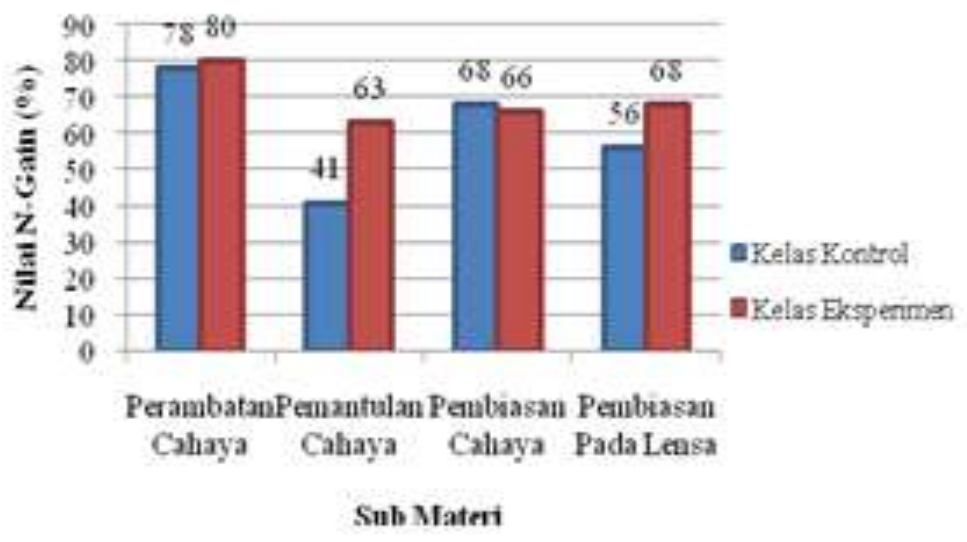

Diagram 1 Perbandingan Peningkatan Hasil Belajar Kedua Kelas Sampel Per Sub Materi.

Dari diagram 1 dapat dilhat bahwa perbedaan peningkatan hasil belajar di setiap materi kedua kelas menunjukkan perbedaan tertinggi pada sub materi perambatan cahaya yaitu sebesar $78 \%$ pada kelas kontrol dan $80 \%$ pada kelas eksperimen. Hal ini berarti informasi yang diterima oleh siswa di kedua kelas sampel mengenai konsep perambatan cahaya cukup merata. Hal tersebut disebabkan karena simulasi interaktif yang digunakan pada kelas eksperimen untuk menjelaskan konsep ini masih sederhana.

Sedangkan perbedaan terkecil pada sub materi pemantulan cahaya yaitu sebesar $41 \%$ pada kelas kontrol dan $63 \%$ pada kelas eksperimen. Rendahnya peningkatan hasil belajar pada sub materi ini disebabkan karena pada sub materi ini tidak hanya membahas tentang pemantulan cahaya saja, tetapi lebih banyak mengenai cermin datar, cekung, dan cembung. Sehingga siswa dituntut menguasai cakupan sub materi yang lebih luas.

Pada sub materi pembiasan cahaya, data hasil pengolahan data menunjukkan bahwa siswa kelas kontrol dengan peningkatan sebesar $68 \%$ lebih baik nilai peningkatan hasil belajarnya daripada kelas eksperimen yaitu sebesar 66\%. Perbedaan hasil Ngain pada sub materi ini terjadi karena ada beberapa faktor eksternal yang tidak bisa peneliti kontrol yaitu, pertemuan ketiga pada fase ke-5 untuk menganalisis dan mengevaluasi proses pemecahan masalah tidak sepenuhnya bisa diterapkan. Hal ini terjadi karena pada fase ke-5 konsentrasi siswa sudah berkurang karena mendekati jam istirahat. Sehingga ketika proses belajar mengajar berlangsung, siswa tidak menerima materi dengan fokus. Hal ini merupakan salah satu kelemahan model pembelajaran berbasis masalah yaitu bagi siswa yang malas tujuan dari model tersebut tidak dapat tercapai sehingga hal ini yang menyebabkan kurangnya pengetahuan yang diperoleh siswa pada sub materi ini [8].

Pada sub materi pembiasan pada lensa menunjukkan nilai kelas kontrol sebesar 56\%, sedangkan kelas eksperimen 68\%. Hal ini menunjukkan bahwa secara rata-rata, peningkatan hasil belajar per sub materi cahaya siswa kelas eksperimen mengalami peningkatan yang lebih tinggi dibandingkan siswa kelas kontrol.

Ketika pembelajaran berlangsung di kedua kelompok sampel, dapat teramati oleh peneliti bahwa ketiga aspek penyusun IPA (fisika) yang meliputi sikap, proses, dan produk dapat terlaksana. Hal ini terlihat pada sikap antusias siswa ketika melakukan kegiatan percobaan. Selain itu sikap lain yang teramati adalah sikap kompetitif, setiap kelompok berusaha untuk menunjukkan hasil terbaik pada setiap melaporkan hasil percobaannya. Aspek selanjutnya yakni proses yang muncul saat siswa memecahkan masalah yang diberikan pada LKS melalui suatu prosedur yang ilmiah dan sistematis. Aspek produk muncul setelah siswa memperoleh jawaban dari masalah yang dipertanyakan pada LKS berupa penarikan kesimpulan yang nantinya merujuk pada hukum atau teori fisika tentang materi yang dibahas.

Pada saat proses pembelajaran berlangsung terdapat beberapa hambatan yang peneliti alami ketika melakukan kegiatan penelitian, yaitu pada pertemuan pertama pada fase mengorganisasikan peserta didik untuk meneliti, suasana kelas yang gaduh dan ribut ketika dibagikan kelompoknya. Hambatan selanjutnya pada fase membantu penyelidikan mandiri dan kelompok, siswa kesulitan mengerjakan LKS, mereka merasa kesulitan cara menganalis masalah dan menyatakan hipotesis. Hambatan selanjutnya yaitu, beberapa kelompok 
masih bingung mengoperasikan simulasi interaktif, karena merupakan pengalaman pertama mereka berinteraksi dengan simulasi interaktif. Karena beberapa hambatan ini maka alokasi waktu yang dibutuhkan untuk menerapkan model pembelajaran ini lebih lama, sehingga dibutuhkan keterampilan pengelolaan waktu yang lebih baik agar terlaksananya semua fase-fase pembelajarannya dan tujuan-tujuan pembelajaran tercapai.

\section{Penutup}

Penerapan model pembelajaran berbasis masalah berbantuan simulasi interaktif berpengaruh terhadap hasil belajar fisika siswa kelas VIII SMPN 1 Pujut tahun pelajaran 2013/2014. Hal ini terlihat pada peningkatan hasil belajar fisika siswa per sub materi cahaya.

Adapun saran yang dapat diberikan bagi guru fisika adalah model pembelajaran berbasis masalah berbantuan simulasi interaktif dapat dijadikan alternatif model pembelajaran yang dapat diterapkan dalam mengajarkan IPA (Fisika). Namun, dalam penerapannya memerlukan perencanaan dan persiapan yang matang sebelum diterapkan di kelas agar proses pembelajaran dapat berjalan sesuai dengan tujuan pembelajaran yang hendak dicapai. Sedangkan untuk penelitian selanjutnya, penggunaan model pembelajaran berbasis masalah berbantuan simulasi interatif dapat dilakukan pada materi yang berbeda dengan subjek penelitian yang lebih luas.

\section{UCAPAN TERIMA KASIH}

Terima kasih yang sebesar-besarnya penulis sampaikan kepada Bapak Dr. H. Wildan, M.Pd, dan Bapak Dr. Karnan, M.Si., Bapak Dr. Ahmad Harjono, S.Si., M.Pd. serta semua pihak lain yang telah membantu penelitian ini.

\section{REFERENSI}

[1] Prasetyo, Z.K. Wahyana, Mundilarto, Subiakto, dan Abdullah, A.A. 2004. Materi Pokok Kapita Selekta Pembelajaran Fisika. Jakarta: Universitas Terbuka.

[2] Trianto. 2012. Model Pembelajaran Terpadu. Jakarta: Bumi Aksara.

[3] Sugiyanto. 2010. Model-model Pembelajaran Inovatif. Surakarta: Yuma Pustaka.

[4] Arsyad, A. 2011. Media Pembelajaran. Jakarta: Rajawali Pers.

[5] Sugiyono. 2010. Metode Penelitian Kuantitatif Kualitatif dan $R \& D$. Bandung: Alfabeta.

[6] Munggaran, D.R. 2011. Penerapan Model Pembelajaran Problem Based Instrution untuk Meningkatkan Hasil Belajar Siswa. Skripsi Jurusan Pendidikan Fisika. UPI Bandung.

[7] Yahya, F. 2012. Pengaruh Model Pembelajaran Berbasis Masalah Berbantuan Simulasi Interaktif Terhadap Penguasaan Konsep dan Keterampilan Generic Sains Siswa Kelas XI SMA Negeri 5 Mataram. Skripsi Jurusan Pendidikan Fisika. Universitas Mataram.

[8] Jauhar, M. 2011. Implementasi Paikem dari Behavioristik sampai Konstruktivistik. Jakarta: Prestasi Pustaka.

\section{Biografi Penulis}

Winarni Listiawati, lahir di sebuah desa kecil di Lombok Tengah, tepatnya di Desa Sengkol tanggal 25 Maret 1991 silam. Penulis menyelesaikan bangku pendidikan SD, SMP, dan SMA di Sengkol. Kemudian melanjutkan studinya di Universitas Mataram pada FKIP mengambil Program Studi Pendidikan Fisika (lulus 2010). 